\title{
Mali's Socialism and the Soviet Legal Model ${ }^{*}$
}

\author{
John N. Hazard $\uparrow$
}

With Mali's option for socialism in 1960,1 its leaders turned toward the Soviet Union in search of a model. Yet the model was not to be copied exactly. There was to be no complete reception of Soviet political and legal institutions. The 1960 Constitution $^{2}$ established the guidelines in its preamble: the Republic was "to organize the conditions necessary to the harmonious evolution of the individual and the family within the bosom of a modern society and with respect for the African personality."

Modibo Keita told his 4,500,000 people on the first anniversary of their independence, "Our socialism will not be for us the manifestation of a tendency to copy servilely what others have done."3 A year later he complimented his Kremlin hosts in Moscow by saying at a banquet, "Like you, we are sure of the triumph of socialism. That is why we wanted to visit the sources of this idea, to see with our own eyes, the life of your country and your successes." 4 Yet Keita was an African, and he was not to be overwhelmed, for he added, "Still, your

* This paper is part of a continuing comparison of African socialist law with Marxian socialist law initiated in 1964 under a Ford Foundaton grant to the University of Dakar. Appreciation for having been given access to Malian materials during an autumn visit in 1966 to Bamako is due the Director of the Ecole National d'Administration, members of the Supreme Court and of the Ministry of Justice, as well as to the law libraries of the Universities of Paris and Dakar. None of those who assisted is, of course, responsible elther for the selection of materials or for the views expressed. Translations from the French are by the author.

$\dagger$ Professor of Law, Columbia University. A.B. 1930, Yale University; LL.B، 1934, Harvard University; J.S.D. 1939, University of Chicago.

1. See generally 2e Seminaire de L'Union SOUdanaise-R.D.A. Baniko les 5.6.7 SeirT, 1962, at 23 (Bamako, no date) [hereinafter cited as 2e SEMINAIRE].

2. Law No. 60-1, Sept. 22, 1960, [1960] Journal OfFiciel dE LA RÉrumligue du MALt [hereinafter cited as JORM] No. 65, at III. This constitution was little changed from the constitutions promulgated to serve the two stages through which the Republic passed before emerging in its present form. After separation from France the territorial asserubly of Soudan declared the territory a "state" on Nov. 24, 1958, and a constitution for the "République Soudanaise" was adopted on Jan. 23, 1959. On federation with Sencgal as the "Fédération du Mali," the first constitution was revised appropriately by Law No. $60-23$, July 26, 1960, [1960] JORM No. 62, at 699. The current constitution was promulgated after separation from Senegal following the crisis of Aug. 20, 1960. Mali retained the name, national anthem and flag of the federation, while Senegal went its scparate way. For a history of these events and the text of the current constitution, see $1 \mathrm{D}$. Lavkows \& G. Peiser, Les Constrtutions Africaines 163 (1961).

3. M. KeITA, Discours et INTERventions 43 (Bamako-Moscow, 1965).

4. Speech by Keita at Kremlin Palace, May 22, 1962, reprinted in KEITA, supra note 8, at 128. 
actual conditions and your methods would differ somewhat from ours." He was for "assimilation" of the Soviet experience, not outright adoption. His aim was to achieve the end already achieved by the Russians, but to do so in his own way.

While Mali's creed, like that of her neighbors in Guinea and Senegal, is a faith combining both socialism and the African component, it is not identical. President Léopold Sédar Senghor argues that he has created in Senegal a mutation of Marxism which deserves to be called "African socialism,"5 but Keita makes no such claims to innovation. Nor is Keita's way what President Ahmed Sékou Touré of Guinea describes as the "non-capitalist way." For Mali's Marxist leaders, socialism in Africa is nothing but the traditional variety, the "universal truth," even though integrated into the realities of Mali's social context. One of Keita's Ministers reports, "We do not pretend to have invented socialism in the Twentieth century, but simply to have sub. jected it to the needs of our country."T

For analysts engaged in comparing the impact on legal institutions of Marxian socialist inspiration, Mali offers a challenging perspective. On the one hand her leaders have gone further in proclaiming their desire to emulate Soviet models than have the Presidents of Senegal or Guinea. On the other hand contemporary Mali is subject to the same historical influences as her two neighbors to the west. She has behind her sixty years of French civilization and legal culture and, as the Malians say, a "millenium" of tribal life before that, and both of these forces have left their mark upon the law.

The question to be explored in this study is the impact in an African environment of what is proudly proclaimed as Marxian orthodoxy. How far has what Mali calls the "universal truth" of Marxian-based socialism, as embodied in the Soviet model, been adapted to meet the social and economic conditions existing in a pivotal state located in the African heartland? The answer may have international political implications as well, for there are those who believe that a state which borrows a model from a great power inclines to accept as well that power's concept of international as well as domestic order.

5. For an analysis of Senegal's legal system based on an interview with Senghor, see Hazard, Negritude, Socialism and the Law, 65 CoLuMr. L. REv. 778 (1965).

6. For an analysis of Guinea's legal system based on an interview with Toure, see Hazard, Guinea's Non-capitalist IVay, 5 Colvas. J. OF Transsut'L L. 231 (1960).

7. 2e SEAINATRE 73. 


\section{The Leadership Component}

Although Marx omitted analysis of leadership from his prescription for the workers of the world in his Manifesto of 1848 , he was quick to fill the gap after the abortion of the weakly-led "Paris Commune" of 1871. Lenin embellished the point so emphatically that today the keystone of the Marxian legal system is everywhere acknowledged to be its leadership core. It is sanctified in the Soviet constitution of 1936 and in the public law of the thirteen other self-declared members of the Marxian socialist legal "family." Whether the form chosen is the single party of the Soviet model or the "leading party" dominating smaller parties in a coalition as in Poland, the rule is clearly stated: there can be no opposition party in the political life of a Marxist state. ${ }^{8}$

Of course, it is not sufficient merely to eliminate opposition. The leadership must take a special form to fit within the model. It cannot be a mass party open to all, but must become an elite, protecting itself against dilution of its militancy through severe restriction of admission to membership. It must exclude all but the militant individual prepared to make self-sacrificing leadership his career. Repeated revelations of careerist practices in Eastern Europe have not altered the imperative laid down by Lenin in 1905. For the Marxian socialists orthodoxy still requires, in the words of the declaration made jointly by twelve communist parties in power in 1957," "guidance by the working class, the core of which is the Marxist-Leninist party."

Mali's social architects have accepted only part of the rule on orthodox leadership: they permit no opposition. Although the constitution declares that normally suffrage is expressed through parties and poli. tical groups, ${ }^{10}$ the "Union-Soudanaise-R.D.A." has in fact monopolized political power. Its only opposition, the "Parti Soudanaise Progressiste," which was affiliated with the French socialists, and the "Parti du Regroupement Soudanaise," were absorbed in 1958 even before Mali's complete independence. ${ }^{11}$ When many of the former opposition leaders

8. To avoid encumbering this paper, citation to the Marxian-socialist legal moclel as manifested in Eastern Europe is omitted herein. Citations may be found in J. HAzAno, LAW AND SOCIAL CHANGE IN THE U.S.S.R. (1953), also in French and Spanish translation as 2 R. DAvid \& J. HAzARd, LE Droir SovietiQue (1954) and EL DEREche Sovietico (1964). See also Hazard, The Soviet Legal Pattern Spreads Abroad, 1964 U. ILL. L.F. 277.

9. Declaration of the Twelve Communist Parties in Power, Nov. 1957, in T1E New Communist Manifesto 169, 176 (2d ed. D. Jacobs 1962).

10. MALI CONST. art. 3.

11. For histories of the early years, see F. SNYDER, ONE-PARTY GOVERNMENT IN MALI: Transition Toward Control 9-79 (1965); Samir Amin, Trois expériences Africaines de DÉveloppement: Le MALI, LA GUINÉE ET LE GHANA 21.75 (1965). 
reappeared on the political scene in 1962, some were charged with plotting subversion and, after admitting their guilt, were sentenced to death. ${ }^{12}$

While the monopoly has thus conformed to orthodoxy in this respect, it departs from the Soviet model on the point deemed cricital by Lenin when he was finally able to organize his Russian Social Democrats as he wished in 1905. Mali's party rejects the orthodox requirement that it include in its membership only the elite. It has been called by its Political Secretary "the party of all the people,"13 thus dramatizing the fact that membership is not restricted to a single class.

In other respects Mali's party follows Lenin's prescriptions. Its members, whatever the extent of their commitment on entry, may not remain mere sympathizers. By party rules they must promise to serve militantly within its ranks, ${ }^{14}$ and party recruiters are advised that "placing party cards is not an end in itself." 15 Potential members must be told that membership means total engagement and sacrifice, and also that "the training of the militants in political theory is an imperious necessity." 16 The party must also be "avant-garde" and its members must be models of selflessness. ${ }^{17}$ Keita reaffirmed this rule in 1966 when he told the party's youth, "I must again put the Party on guard against the bourgeoisification of customs and the tendency to live beyond means." 18 These themes ring sufficiently true to Lenin's to weaken the contrast provided by the rejection of his elitism.

Still the concept of the party as the "party of all the people," which has been the Malian formula since the early days, would have been unthinkable in other Marxian-oriented societies until the Soviet Communist Party's adoption of the same phrase in its program of 1961. Prior to that time communist parties had to be "proletarian class parties" to meet the test of Marxian orthodoxy. While the Chinese

12. DuBois, Mali Five Years after the Referendum, AMERICAN UNIverstr FIELD STAFF REPORTS SERvices, VI WEST AFrich SERIES, No. 3 at 12 (1963). The death sentences were commuted to life imprisonment at hard labor, but the principal leaders were reported killed under mysterious circumstances in 1964 in northeastern Mrali, reputedly when a convoy transporting them from one prison to another was attadied.

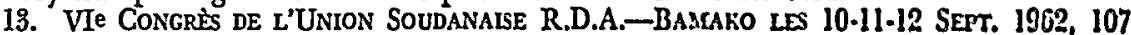
(Bamako, 1963) [hereinafter cited as VIe Concriss]. Part of the procecdings of the V1o Congrès are reported in English translation in F. SNYDER, supra note 11, at 134-52.

14. Rule 3. For rules, see VIe CoNGrìs 107, translated in F. SNYDER, supra note 11, at 134. supra note 11 , at 134 .

15. VIe CONGRÉS 118.

16. Id. 123 .

17. 2e SEMINAIRE 17.

18. Speech on Sixth Anniversary of Independence, given Sept. 22, 1966, reprinted in $L^{\prime}$ Essor, Sept. 26, 1966, at 4, col. 4. 
party has waxed vitriolic in its criticism of Soviet leaders for sponsoring the new formula, Khrushchev justified the change on the theory that, with the complete elimination of capitalists and classes as a result of the revolution in the ownership of productive wealth, the class struggle in the Soviet Union was at an end. He thought that the absence of class enemies in Soviet society left the party free to evolve into a party of all the people, but he did not go so far as to conclude that it should therefore be opened to all. The new Russian formula only eliminated class as a membership requirement. The elite concept characterized by limitation of numbers as well as by insistance upon total engagement was preserved as a cardinal element of the leadership role which the party continued to play.

Malians' unorthodox characterization of their party springs from their belief that "the question of class is quasi-nonexistent."10 They admit to having different strata in their society, but insist that "there are absolutely no violent contradictions between them, no relationships of exploiters to exploited." Nationalism is, therefore, "neither feudal nor bourgeois in form, but is truly a nationalism of the whole people." Moreover, not only do Malians see no capitalism, but they find no need to develop it as a predecessor to socialism. In support of this conclusion, they cite a 1920 address to the Communist International in which Lenin argued that the capitalist stage could be skipped by backward countries moving to socialism after the first world war. ${ }^{20}$ With no class struggle to worry about, the monopoly party requires no class component to fight its battles. It need not even follow Guinea's example in attacking that fringe group of capitalists, the merchants. Even they may join the party if they share its goals.

In organization the Malian party is orthodox. Thus, "democratic centralism" as prescribed by Lenin is the organizing principle and it is described in traditional terms: "Acceptance of the law of the majority within our organization; acceptance by the minority which has taken a position on a given subject of the duty to defend the solution adopted by the majority." 21 This rule is accompanied by the familiar Marxian prescriptions:

The spirit of discipline is the base principle; a decision once taken must be accepted by the militant even if he has proposed a different solution. No one may conduct a campaign for the can.

19. 2e SEMINAIRE 74.

20. Id. 75.

21. VIe ConGrìs 128. 
didacy of a militant before the latter is nominated by a competent organization. The party may take sanctions running from warning to exclusion. ${ }^{22}$

On the other hand, every member is left free to express his views, so long as he refrains from organizing a faction to support them. ${ }^{23}$

On only one point of party discipline is there a striking contrast with the Soviet model. The party "has erected as a fundamental principle freedom of religious opinion." 24 This concession goes farther than that of the Soviet constitution, which extends a guarantee of freedom of conscience to the citizen; the Malian guarantee extends to party members as well, for there is no requirement that a member be an atheist. On the contrary, Keita has expressly rejected atheism. In a 1962 speech to the students of journalism he asked,

How then, it is said, can religion and socialism be conciliated? I say that the question rests on heresy. If in the Republic of Mali religion had been the instrument of oppression and domination, if it had made itself the agent of the colonial system, or even if in our remote past it had been an instrument of the fuedal system, if it had played the role of poison, as a factor making for resignation, then the struggle could be justified..$^{25}$

After distinguishing the Malian experience from the conditions cited by Marx to show that religion is the opium of the people, and by Lenin to justify the destruction of religious institutions in Russia as instruments of the Tsarist state, Keita went on to embrace Islam as socialism's own. He declared, "There is no religion more socialist than the Moslem religion, because it teaches among its principles that the rich must give to the poor, must divide their goods in order to relieve the suffering of others."26

Party structure in Mali is mindful of that of the Communist Party of the Soviet Union. There is the familiar pyramid, resting on the comite at the level of the village, the city quartier and the nomadic fraction. Above is the sous-section in the geographically defined arrondissement and above that the section at the level of the cercle in the state administrative apparatus. ${ }^{27}$ Crowning the pyramid is the Party Congress, which elects its National Political Bureau. Each level is di-

22. 2e SEMINAIRE 15.

23. Id. 16.

24. Id. 17.

25. M. KerTA, supra note 3, at 107-08.

26. Id. 108.

27. VIe Congrìs 144. 
rected by an executive committee, which looks upward as well as to its parent body for guidance.

What structural variation on the Soviet model there is stems from the fact that Mali's party originally made no organization in the factories and ministries along production lines. Lenin had insisted that such organization was essential, but only since 1962 has Mali's Party begun to move in this direction. ${ }^{28}$ Then, it authorized creation of "political groups," designed to play a role as "brigades of socialist labor" in factories and shops. These groups, however, are not basic membership units like their Soviet counterparts, but rather coordinating units for those who belong to comités in different quarters but work together in the same place.

This Malian variation from Lenin's pattern may be the result of three factors: (I) a dissimilar history, in that Mali's comités, unlike the original Russian soviets, did not originate as conspiratorial groups created by workers to fight the regime from as secure a position as possible; (2) the absence until recently of more than a very few industrial units in Mali; and (3) the emphasis upon all the people rather than upon a class as the Party's base, making organization by class groups unnecessary.

The supporting youth organizations follow Soviet models, ${ }^{20}$ except that in 1962 the top leadership committee of Malian youth was abolished, for fear that its chief might become a contender for political power. ${ }^{30}$ Direction was passed to the National Political Bureau of the Party to assure conformity to official policy.1 ${ }^{31}$ The Soviet model calls for indirect control, to be exercised by over-age members of the Party strategically placed in the various levels of the youth organizations, but Mali's 1962 decision abandoned this method of control altogether by establishing a maximum age limit of 25 for all members. ${ }^{32}$

Younger recruits belong, as in the U.S.S.R., to the "Pioneers," which enlists children from the ages of 7 to 18 . Its mission is the same as that in the Soviet model: to educate youth in all fields, political, economic, civic, cultural, social and artistic. ${ }^{33}$ In deference to venerable custom, women, who have always been fully integrated in the party structure

28. Id. 180. English translation in F. SNYDER, supra note 11, at 144.

29. VIe Congrìs 146.

30. DuBois, supra note 12 , at 7 .

31. VIe CONGREs 180.

32. A resolution to restore the top age limit to 30 was adopted by the Youth organization in April, 1966, but it awaits approval of a Party Congress before becoming effective.

33. VIe CONGRìs 147. 
in the U.S.S.R. without a separate organization, have had to be organized separately in Mali.

The collegial system of leadership is espoused at all levels in the Malian party, ${ }^{34}$ as it is in principle in the U.S.S.R., but Malians have faced some of the same temptations of power and some of the same needs for strong leadership as have the Soviet Communists. Personalization of leadership has forced Modiba Keita to the fore, and his personality has left a strong imprint upon the Party. He is so greatly praised and revered that at least one outside observer has found a "cult of personality" around him. ${ }^{35}$ Readers of the Party's newspaper, L'Essor, can see a resemblance to Stalin's Pravda. Still, there is no Malian "Stalinism." Keita is more like Nikita Khrushchev, a first among equals, and another outsider has concluded that Keita has no choice but to maintain the collegial form because the Political Bureau's power is actually shared among its members, who speak for the large ethnic and regional groups they severally represent. ${ }^{30}$ Even had he the will to do so, no individual could become a dictator at present.

\section{Party-State Relations}

The concept of the Party as a party of all the people, open to all, has not brought its leaders to conclude with Sékou Touré in Guinea that there can be a merger of party and state organs at the local level. For the Malians the Party "conceives" and the state "executes." The Council of Ministers as the supreme executive has the duty of guiding the administrative apparatus in execution of tasks set by the Party. Lenin's admonition that there be a minimum of crossing of lines is honored by a rule that no party official or organization shall substitute himself or itself for an administrator. ${ }^{37}$

As in the U.S.S.R., administrators are reminded that their duty is to seek advice from responsible political officials because all administrative acts have political repercussions. ${ }^{38}$ Similarly, party people must advise when advice seems necessary. Mali has faced the same problem of balance between party and administration which beset the Soviet Union, especially during the war and under Khrushchev's policy of

34. Id. 180

35. F. SNYDER, supra note 11, at 112.

36. DuBois, supra note 12 , at 5 .

37. 2e SEMINAIRE 18-19.

38. An African political scientist concludes that in Mali constitutional organs are subordinated to Party organs more than in-Guinea. SEYDou MAdANI SY, Rzcherchies sur I'EXERCISE DES POUVOIRS EN AFRIQUE NOIR: COTE D'TYOTRE, GuINEE, ALALI 165-65 (1965). 
direct party concern with agriculture. Mali's party people have found it hard to resist putting their hands to the wheel as well as their pens to paper, but the rule is still embodied in the three principles of orthodoxy expressed by the slogan, "primacy of politics, non-meddling and politico-administrative coordination." 30 Further, an administrative official is required to be militant, at whatever level he serves. "His first duty is to apply the principles of the Party."40 As in the Soviet system, there is no concept of the apolitical civil servant above the political fray. The Party says that no administrator can be permitted for lack of political acumen to shake public confidence, to make the public regret the passing of the colonial regime, or even to remind it of the old methods.

Leadership is not stressed to the exclusion of mass participation, but this latter desideratum is not pressed as strongly in Mali as in the Soviet Union. Mali makes the familiar claim that "the practice of democracy goes well beyond classic democracy,"41 but the fact belies the theory. There is always a veto at the center.

At the village level there is in fact a measure of mass participation through a village council, ${ }^{42}$ which is elected by universal suffrage and may include women as well as men..$^{43}$ It serves as a deliberative organ, but operates primarily as a conciliator. It must resolve disputes over land and property matters, i.e. administration of the common fields, ponds, rivers, forests and quarries, and it must deal with economic problems concerning the whole village community. It is also charged with maintaining public order, protecting individuals and their property, administering the local police and supervising certain health matters, the streets, the trails and diverse financial matters. These councils have been called "a marvelous school for apprenticeship in democracy and administration of public affairs." 44 Lenin conceived of his soviets similarly. Yet while the village soviet in the U.S.S.R. elects its own executive committee, the Malian village council can only nominate the "village chief"; he is appointed by the central government. He is thus even more directly dependent on the center than the soviet village executive, although Lenin's system of dual subordination does make the latter both subservient to the executive committee of the next

39. 2e Seminaire 19.

40. Id. 29.

41. Id. 30 .

42. These were organized within the République Soudanaise by Ordinance No. 48

D.I., March 28, 1959, and were continued by Mali.

43. Law No. 63-32 AN, May 31, 1963, [1963] JORM No. 147, at 382.

44. 2e SEMINAIRE 31 . 
higher soviet in the hierarchy and responsible to the soviet from which the local executive committee's authority stems.

"Alongside the village council, organ of administration and execution, is the political apparatus of the community, elected by all the militants of the village: the village comite.". 15 The comite's function with relation to the village council is stated in orthodox terms as, "first of all the role of mobilization in the bosom of the masses, which it is charged to educate." Current Marxist-Leninist manuals in the U.S.S.R. call this "directed democracy."

Municipalities are governed as "communes" through a popularly elected Municipal Council, ${ }^{40}$ which chooses the Mayor and his deputies from its members. Varying in size from 17 to 61 depending on the size of the city, a Council's life continues until it is dissolved by the National Assembly, although its activities may be suspended by decision of the Council of Ministers for periods of up to three months. It does provide a vehicle for mass participation in public life, but its practical authority is limited. On nine enumerated critical legislative matters, it can do no more than give advice and express wishes unless it has the consent of the Minister of the Interior. Large expenditures and borrowing of any size must be approved by the Council of Ministers itself.

At intermediate levels there are further departures from the Soviet model of public representation, for here the Malian masses do not participate at all. Where the Soviet system has an assembly, Mali places a "chief" between the village and the cercle, in what is called in continuation of French terminology the arrondissement. 4 Named by the central authorities and directly subordinated to the commandant of the cercle, these 226 officials are indubitably the center's men. Their critical political importance is evidenced by the rule that they must be political figures of proven responsibility. They must not only administer but share in the political education of the Party's comités within their district. Thus, they combine formally in their persons both party and state lines of authority as is never the case in the U.S.S.R.-and as would indeed seem superfluous to the Soviet party, since the chiefs operate in an area in which there is already a sous-section of the Party capable, one would suppose, of political education of the comites in the

45. Id.

46. Law No. 66-9 AN, March 31, 1966, [1966] JORMI No. 218, at VII.

47. See Mali CoNsr. art. 41 for territorial divisions. For comments on the role of the cercle, see 2e SEMINAIRE 32-33. 
arrondissement. These remarkable figures, heirs to the old tribal chiefs, have the additional function of conciliation of civil and commercial disputes between villages or between residents of different villages.

The commandants of the 42 cercles are similarly conceived. Named by the Governor of the next higher unit, the Region, they represent central authority, but they maintain a special relation to the Party at their level as ex officio members of the political bureau of the Party's section. ${ }^{48}$ Through this device Malians attempt to maintain what the U.S.S.R. seeks through the medium of the county assemblies of the soviets, namely close coordination between the administrative apparatus and the local residents on economic, social and cultural matters.

The same administrative pattern is repeated at the regional level, although here there is a beginning of a movement toward closer sim. ilarity to the Soviet system. The six Regional Governors are named by the center, but are instructed to work closely with the Party organs in the Region's cercles, arrondissements and villages, though they do not enjoy membership in any of these bodies. ${ }^{40}$ The Governors' primary function is formulation and execution of the economic plan for the Regions, and to aid them in this task a commission to regulate financial matters was established in each of their offices in 1962. Its members are the responsible Party officers in all sections of the Region, the resident National Assembly deputies, and the commandants of the cercles. The financial commission was to be expended eventually into a Regional Assembly to be elected by universal suffrige in the manner of the provincial assemblies of the U.S.S.R., but the expansion has not occurred, perhaps because such an assembly might prove to be a means of undermining the Governor's power at a time in the nation's history when centralization seems necessary to stability.

At the top is a National Assembly and a Council of Ministers, presided over by a President who is elected by the Assembly at the opening of each five year term. ${ }^{50}$ This official serves simultaneously as Chief of State, and now bears the title "President of the Republic." French specialist the pattern is "profoundly original" in French-speaking Africa. ${ }^{52}$ The President of the Republic with his government is

48. 2e SEMINAIRE 35 .

49. Id. 37. Law No. 65-22, AN, April 1, 1965, which concerned the powers of the Regional Governors was not found.

50. Malr Const, art. 7.

51. Constitutional law No. 65-9 AN, art. 6, April 16, 1965, [1965] JORM No. 195, at 167.

52. 1 D. Lavroff \& G. Peiser, supra note 2, at 164. The post of Vice-President of the Council of Ministers, originally established by the constitution, has been abolished for the 
responsible to the Assembly, but, in emulation of the French model, the Assembly is automatically dissolved if two ministerial crises occur within twenty-four months. The eighty deputies of the Assembly are elected on a single list prepared by the monopoly Party, ${ }^{23}$ and none is assigned to a specific district. This system is designed to promote identification with national rather than regional interests.

As might be expected under the Malian non-class approach, suffrage is open to all except certain criminals. There is no effort to exclude bourgeois elements, as there was under Soviet constitutions prior to 1936.54

Party concern with the details of state affairs was increased in 1966 by creation within the Central Secretariat of five committees: for politics, for economic and financial matters, for administrative and judicial matters, for social and cultural affairs, and for the press. These committees are charged with making "profound" studies of all matters of interest to both Party and State. In a sense they assume some state functions, for they are described as "veritable departments at the level of the National Political Bureau; functioning with well-tried cadres, they must be veritable instruments of affirmation of the primacy of the Party." 55 In a speech two days after formation of the commissions, Keita reaffirmed their fundamental purpose:

I should remind you once more of the primacy of the Party over the administrative and legislative organs, which is embodied in the right of all levels of the Party to conceive the whole policy of the country (economic, social and cultural) and by the right to see to the execution at the same level of that which has been conceived and whose execution is the task of administrative and legislative organs. ${ }^{56}$

\section{Economic Planning and Financial Credit}

The dimensions of the new state's economic problems were set forth by the Ministry of Planning in 1959, while Mali was still in federation

stated purpose of avoiding confusion of authority. Law No, 61-25 AN, Jan. 20, 1961, [1981] JORM No. 80, at 245 .

53. Ordinance No. 65 bis on the Electoral Law, Nov. 24, 1960, [1960] JORAr No. 73, at I.

54. Law No. 63-73 AN, Dec 26, 1963, [1964] JORMI No. 163, at 165.

55. "Session Ordinaire de Bureau Politique National," Sept. 20, 1966, L'Essor, Sept. 26, 1966, at 8, col. 4 .

56. Speech on Sixth Anniversary of Independence, Sept. 22, 1966, L'Essor, Sept. 20, 1966, at 3, col. 3. Dramatic evidence of the interrelationship is provided by a protocol ranking of Party and State officials, issued as a guide to foreign diplomats and others needing to be informed of precedence of rank when both Party and State offcials are present on the same occasion. See 271, PG, Nov. 26, 1962, [1962] JORMI No. 133, at 932. 
with Senegal. ${ }^{57}$ Per capita income was $\$ 56$ a year, less than that of India and the Belgian Congo, while per capita consumption, to the extent that it could be determined by household accounts, was about $\$ 50$ per year, placing Mali below the average among all former French colonies The rural population constituted 92 per cent of the whole, and accounted for 60 per cent of the country's total consumption, but per capita food consumption was much lower than in most other countries of sub-Sahara Africa.

A second report in $1963^{58}$ provided insight into the industrial and commercial complex. At the end of 1962, there were only 883 function. ing "enterprises," of which 44 were engaged in agricultural pursuits and 44 more in industrial. The rest were in commerce and banking (289), the liberal professions (51), transportation (43), construction (32) and public services (380). These enterprises employed a total of 18,823 salaried workers. ${ }^{59}$ The number of employees in state enterprises was, however, expanding rapidly in number as additional socialist policies were put into effect.

Marxian socialists' greatest pride is state economic planning, and Mali's leaders began immediately after independence to construct a typical system. The constitution gives the National Assembly authority to fix fundamental principles for the organization of production..$^{60}$ A Committee of Economic Direction was established in 1960, to which the Ministry of Economic Direction submits proposals. ${ }^{01}$ A Planning Ministry was put in place, within which were formed a Planning and General Statistical Service ${ }^{62}$ and an Action Rurale to aid in forming cooperatives and in drafting legislation on the subject. ${ }^{63}$ The first compulsory plan was inaugurated on July 1, 1961, to run for five years, but it was subsequently frequently revised downward. In 1964, the National Assembly adopted a less ambitious investment schedule for economic and social development, ${ }^{64}$ and the year 1966 brought still

\footnotetext{
57. République du Mali, Ministikre du Plan et de la Coordination des Affairs ECONOMIQUeS ET FINANCTÈres, COMPTES ECONOMIQUES DE LA RÉPUBLIQUE dU MALI 1959, at 2 (Bamako, no date).

58. République du Mali, Ministère d’état Chargé du Plan et de la Coordination des

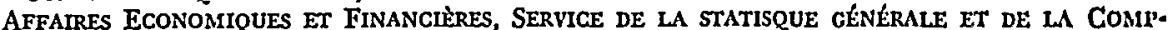
tabilite nationale, Bulietin AnNuel de la Conjunction, Situation Economique du MaLr AU 31 Dec. 1962 (April 1963).

59. Id. 20.

60. MALI CONST, art. 24.

61. Decree No. 268, Oct. 12, 1960, [1960] JORM No. 68, at 853.

62. Law No. 61-65 AN, May 18, 1961, [1961] JORM No. 90, at XXII, reorganized by

Decree No. 46 PG, April 4, 1964, [1964] JORM No. 169, at 358.

63. Law No. 61-66 AN, May 16, 1961, [1961] JORM No. 90, at XXII.

64. Law No. 63-95 AN, Jan. 25, 1964, [1964] JORM No. 162, at 104.
} 
further revision of the plan in the direction of retrenchment. The 1966 "budget of consolidation" sought equilibrium between needs and means through a limitation of imports destined for current consumption on the one hand and an increase in production on the other. Agriculture was favored so as to expand the essential base of the economy, but the budget for industrial equipment was cut proportionately.

Heeding Lenin's strictures on the need for control of credit, Mali's leaders established exchange controls immediately after separation from Senegal. ${ }^{65}$ This measure was followed by a law requiring private insurance companies to invest in Mali 5 per cent of their 1960 premiums-and all profits in excess of the required reserves thereafterunder a program to be approved by the Ministry of Commerce and Industry. ${ }^{66}$ Banking came under the control of a Malian Credit Council charged with establishing a credit policy for the republic, coordinating banking, and issuing currency. ${ }^{67}$ A Savings Bank system to be administered within the post offices was created at the same time. ${ }^{68}$

The state early assumed the role of principal banker to the economy. After 1960, national enterprises were financed by the "Banque Populaire du Mali," a state bank created expressly for that purpose.63 Another important bank was a mixed company, whose capital was provided jointly by the state treasury and the renowned French Credit Lyonnais. ${ }^{70}$ But in 1962, the government administered a virtual cout $p$ de grâce to foreign banking. It severed its links with the Franc zone by establishing a new Central Bank ${ }^{71}$ and issuing its own currency ${ }^{72}$ in place of the French African Community francs it had previously used. Keita went before the National Assembly to explain the necessity for this radical step, saying,

Dear colleagues, as far as we go back in time history teaches us that political power always and necessarily is accompanied by the

65. Ordinance No. 13 P.C., Sept. 17, 1960, referred to in Seydou Mindant Sr, supre note 38 , at 51 . The regulation on exchange control is Decision of Nov. 20, 1960, [1960] JORMS No. 73 , at IV.

66. Decree No. 139 PG, April 6, 1961, [1961] JORMI No. 83, at 381. Forign insurance companies were regulated further by decree No. 32 PG, Mrarch 9, 1964, [1961] JORMS No. 167 , at 263.

67. Decree No. 155 PG, April 6, 1961, [1961] JORMI No. 83, at 383.

68. Decree No. I71 PG, April 20, 1961, [1961] JORMI No. 83, at 404.

69. The statute has not been found, but the fact is stated in SErdou dLadasi Sr, supra note 38 , at 51 .

70. The statute has not been found, but the fact is stated in 20 SEMmaine 63.

71. Law No. 62-55 AN, June 30, 1962, [1962] JORMI No. 120, at I. The Central Bank was expanded in 1964 to include the Central Office of Mrutual Agricultural Credit. Law No. 64-2 AN, May 14, 1964, [1964] JORM No. 172, at 434.

72. Law No. 62-54 AN, June 30, 1962, [1962] JORir No. 120, at III. 
royal power to coin money, that monetary power is inseparable from national sovereignty, that it is the indispensable complement of it, the essential attribute. ${ }^{73}$

The French banks by and large saw the handwriting on the wall and withdrew. The Banque Nationale pour le Commerce et l'Industrie closed on January 6,1963 , followed closely by the Banque du Commerce Africain on February 15. Only the Banque de l'Afrique Occidentale remained as a representative of the private bankers. Its building still stands on one of Bamako's main streets, presenting a distinctive appearance of affluence. Some say it is protected because it has advanced important credits to Malian state enterprises, ${ }^{74}$ but the major credit source for such state development is now the Central Bank, which absorbed the Banque Populaire on January 25, 1963. ${ }^{75}$

\section{Industry and Commerce}

While leaving a semblance of private enterprise in the banking field, like all orthodox Marxists Mali's leaders have sought to capture the commanding industrial and commercial heights. Under the economic plan of July 1, 1961, development of all new industries operating as textile factories, slaughter houses, refrigeration plants, petroleum refineries, canning plants, and sources of construction materials is monopolized by the state. ${ }^{76}$ But even before this, the state was reaching into existing private enterprises. An important company exploiting navigation and associated activities in the Niger River valley was recreated in 1960 as a mixed company to which the government and the Société des Messageries Africaines jointly contributed the capital. ${ }^{77}$ The government's shares were made non-transferable, as were the private company's shares for the first two years. Later, in 1962, the private shares were bought by the state and a new company formed as a public corporation. ${ }^{78}$

Following the same pattern the state assumed responsibility in stages for the Bamako airport, ${ }^{78}$ Air Mali, ${ }^{80}$ electric and water services, ${ }^{81}$

73. Speech to the National Assembly, June 30, 1962, in M. KeITA, supra note 8, at $141-42$.

74. DuBois, supra note 12 , at 15 .

75. Law No. 63-27 AN, Jan. 25, 1963, [1963] JORM No. 138, at 120.

76. SAMIR Amin, supra note 11, at 77-78.

77. Law No. 60-25, Aug. 8, 1960, [1960] JORM No. 62.

78. Law No. 62-11, Jan. 15, 1962, [1962] JORM No. 110, at 115.

79. Ordinance No. 30 PG, Oct. 26, 1960, [1960] JORM No. 69, at 893.

80. Ordinance No. 31 PG, Oct. 27, 1960, [1960] JORM No. 69, at 894.

81. Ordinance No. 26 PGP, Oct. 14, 1960, [1960] JORM No. 73, at $X$, as amended by concession contract, Law No. 62-58 AN, Aug. 6, 1962, [1962] JORM No. 125, at 533. 
railroads, ${ }^{82}$ posts and telegraph, ${ }^{83}$ petroleum exploitation, ${ }^{81}$ canning, ${ }^{85}$ brickmaking, ${ }^{86}$ hotel management, ${ }^{87}$ and public works. ${ }^{88}$ For all, the final institutional form was the public corporation, created in the image of the enterprise developed by Lenin beginning in 1923 and since adopted as the standard operating unit for state economic activity throughout the Marxian socialist world. ${ }^{80}$

A model statute for public corporations was enacted in 1963.50 Existing statutes were reissued in the new form, ${ }^{01}$ which begins with a preamble in Marxist language reading,

Born in the struggle for economic independence of the country, the national enterprises are a decisive victory for the toilers of the Republic of Mali. These enterprises belong to the entire Malian people; they are the people's property. The exploitation of man by man is abolished in them once and for all, and a new type of labor is beginning to develop in them. In these enterprises the toilers work for all of society-for themselves. To protect and increase continually the property of the People in these enterprises is, therefore, the duty of every toiler.

Mali's leadership is concerned only with the commanding economic heights, not with the entire economy as the U.S.S.R. model requires. A 1962 laww $^{92}$ establishing the terms for private investment makes this clear. The Ministry of Planning was authorized to sign conventions authorizing investment with "all enterprises whose activity presents a special interest for the Malian economy and whose creation or investment program concurs with the provisions of the plan of economic and social development of the Republic of Mali."

Investment was limited to production facilities by the simple device of a clause excluding commercial enterprises, from the regime. ${ }^{33}$ The

82. Ordinance No. 62 bis PGP, Nov. 29, 1960, [1961] JORM No. 78, at XI.

83. Ordinance No. 62 PGP, Nov, 29, 1960, [1961] JORMI No. 78, at VI.

84. Law No. 62-41 AN, April 24, 1962, [1962] JOKAI No. 118, at 372.

85. Ordinance not found creating the enterprise, but it was given irrigated land from Office du Niger by Decree No. 93 PG, May 7, 1963, [1969] JORMI No. 145, at 319. Use was for an unlimited period of time.

86. Law No. 69-50 AN, May 31, 1963, [1963] JORA No. 147 at 386.

87. Law No. 64-23 AN, July 15, 1964, [1963] JORMr No. 183, at XII. The corporation was placed under the Ministry of Information and Tourism. No monopoly was created over hotels. The Majestic, a private hotel of considerable size, continues to function in Bamako.

88. Law No. 65-9 AN, March 13, 1965, [1965] JORA No. 195, at 179.

89. Provisions governing administration are set forth below in the paragraphs devoted to labor.

90. Jan. 26, 1963. Statute not found but identified in SEYdou MCADANI Sy, supra note 33,

91. Law No. 63-65 AN, Dec. 26, 1963, [1964] JORM No. 162, at 112

92. Law No. 62-5 AN, Jan. 5, 1962, [1962] JORA No. 110, at 112.

93. Id. § 4 . 
Malians were showing typical Marxist aversion to the middleman as a non-contributor to value, but they were also acting out of fear. They considered the merchants a potential threat to the regime, and history proved the fear well-founded. On July 20, 1962, public demonstrations developed in the Bamako market of such magnitude that the police found it necessary to make 250 arrests, and the former leaders of the pre-independence opposition were tried for inciting the merchants to treason. ${ }^{94}$

Under the investment code any enterprise with which a convention is signed has the right to retransfer the investment, but on the expiration of the term, buildings and installations revert to the state without indemnity..$^{95} \mathrm{~A}$ model convention was attached to the statute. The state can limit profits by taking advantage of a clause which permits state representatives to share with the enterprise's owners in establishing the production plan and in fixing prices. In practice foreign companies have been permitted to repatriate annually 25 per cent of their profits, but the remaining 75 per cent must be reinvested within Mali in keeping with the provisions of the economic plan. ${ }^{90}$

Fear of merchants also led to a policy of control of foreign commerce, which has always been vital to the Malian economy. Pharmaceuticals were placed immediately in the hands of a public corporation. ${ }^{07}$ Another public corporation named SOMIEX was created within the Ministry of Commerce and Industry to monopolize trade in the primary export product, peanuts, and eleven basic imports. ${ }^{08}$ Rural cooperatives were required to sell and buy only through it. Other public corporations soon monopolized all agricultural exports from the Niger Valley ${ }^{90}$ and the export of hides. ${ }^{100}$

Outside foreign commerce, however, Malian policy called only for price control and for licensing of those private merchants who were

94. DuBois, supra note 12 , at 8-12.

95. Law No. 62-5 AN, $\S 18$, Jan. 5, 1962, [1962] JORM No. 110, at 112. For examples of concession agreements, see that with Tranduy Co. S.A. of Geneva to install a laboratory to package and test pharmaceuticals in Bamako, Decree No. 225 PG, Nov. 13, 1963, [1969] JORM No. 158, at 699, and that with Compagnie Française pour le Développement dit Textile to provide individual assistance, Decree No. 44 PG, April 1, 1964, [1964] JORM No. 168 , at 294 .

96. DuBois, supra note 12 , at 15 .

97. Ordinance No. 18, Oct. 15, 1960, [1960] JORM No. 67, at 808.

98. Ordinance No. 33, Oct. 29, 1960, [1960] JORM No. 69, at 899.

99. Ordinance, No. 49 PGP, Nov. 18, 1960, creating "Office du Niger" [1960] JORM No. 70 , at 948.

100. Decree No. 12 PG, Feb. 2, 1964, creating "Sonea," [1964] JORM No. 163, at 181. 
to function in domestic markets. A 1961 decree $^{101}$ regulated prices in an all-inclusive manner:

The importation, exportation, circulation, manner of fixing prices; the detention, declaration, and control of inventories; the use; the putting up for sale; the advertising of prices for all products and articles of merchandise of whatever origin and source are regulated by decrees.

All merchants must now be licensed under a 1964 statute, ${ }^{102}$ designed to assure stability and open dealing. While many of the Lebanese formerly doing business have chosen to leave Mali rather than remain under the restrictions, retail trade is still in private hands, though the merchants have little freedom to choose their sources of supply or to set their prices.

When special knowledge is required, Mali's policies have been shown to be sufficiently flexible to admit private enterprise into export industries as well, but only in the form of mixed companies. Thus a Society for the Exportation of Animal Products ${ }^{103}$ was chartered in 1965. The state owned the majority of shares, but the private investors, known as the "Group Mothes," were given half the seats on the administrative council of six members. The state kept the key places, however, reserving the posts of president and director general for its appointees, and obliging the private group to be content with the deputy directorship. Moreover, the private directors had to deposit at least 15 shares as a guarantee of honest direction, while the government's directors were not even obliged to own, much less deposit, any shares. Similarly, in 1965 the radioelectric industry was placed in the hands of a mixed company with 4,000 shares, of which the state was required to hold 60 per cent. Again, an equally divided administrative council of four members was established, of which the president must be Malian. ${ }^{104}$

Keita explained his policy on private enterprise in 1963 as aimed primarily at maintaining equilibrium in the state's balance of payments, through control of foreign commerce in accordance with the provisions of the economic plan. As to merchants, he added,

I know that some merchants are experiencing difficulties in the exercise of their customary pursuits; but since evolution necessar-

101. Decree No. 185 PG, March 2, 1961, [1961] JORMI No. 86, at I, as amended, Decree No. 224 PG, June 6, 1961, [1961] JORMI No. 89, at I.

102. Decree No. 189 PG, Dec. 24, 1964, [1964] JORI I No. 188, at 31.

103. Law No. 65-28 AN, July 2, 1965, [1965] JORM No. 202, at 387.

104. Law No. 65-36 CP-AN, Sept. 13, 1965, [1965] JORMI No. 207, at 525. 
ily creates selection, it is indispensable that those who lack their own resources and who lived under a system of mercantilism during the period of the colonial regime, and who were accomplices in the exploitation of the rural masses by the great foreign companies reconvert themselves to become more useful to themselves and to their country. ${ }^{105}$

He inveighed against fraudulent trade, but assured merchants who conformed to Malian laws that they could count on the Party's desire to sacrifice no stratum of the population, at least so long as the favored strata fully understand their duty and renounce their surplus so that others may live and develop.

Mali's leader was declaring no such war against merchants as Sékou Touré has waged in Guinea, but he was giving his private merchants only a limited role to play under the watchful eye of the Party and the security apparatus intent upon avoiding a repetition of the Bamako market rebellion of 1962. He reaffirmed this position in 1967 at the time of devaluation of the currency. Merchants were castigated for smuggling, but the attack was not directed at them as a class. Those who had remained honest were praised by the government for their proper civic conduct. ${ }^{106}$

\section{Land and Agriculture}

Land law was undergoing revision even before Mali's separation from France. A 1957 decree had established a socialist theme by providing that in specially designated territories, "lands acquired by concession which have not been put in a condition enhancing their value under the law of May 3, 1946 within five years, shall be wholly or partly transferred to the national domain." 107 The decree promised an indemnity amounting to the original cost, adjusted to take into account the increase in living costs, plus the registration fee and the value of any improvements not "sumptuous."

The new Malian government built on this foundation early in 1961 with a law providing that "every building plot or land whose title has been registered but which has been abandoned for six consecutive

105. New Year's Speech to the People of Mali, 1963 in M. KErrA, supra note 8, at 201-04.

106. Speech of Louis Negre, May 5, 1967, Quotidien d'Information, Agence Nationale d'Information du Mali, May 9, 1947, No. 946 (mimeo).

107. For an historical account see Blanc, Chronique fonciere: Quelques los Guindens at Maliennes Récentes, 72 RECEIL PENANT 297 (1962). 
years shall be considered as vacant and incorporated in the national domain." 108 The commandant of the cercle establishes vacancy at a hearing with notice, and claimants have three months to establish their case. No indemnity is paid, on the theory that the land reverts to the state by prescription.

Fairness in transactions involving land transfers or mortgages was the subject of two accompanying decrees of January, 1961. By the first, all transfers of land whether by sale or gift, as well as any act creating an interest in land by mortgage, usufruct or long-term lease, must be submitted to preliminary approval by the government on pain of nullity. ${ }^{109}$ The second provisionally suspends all existing law on the sale of land by forced expropriation. ${ }^{110}$ In addition in May a new procedure requiring governmental approval of sales made by court execution was introduced. ${ }^{111}$

Customary rights in land posed a potential obstacle to development. To overcome it state enterprises needing encumbered land are authorized to address a request to the Minister of Rural Economy, who examines the customary claims and then issues a decree of acquisition and registration in the name of the state. ${ }^{112}$ The procedure was made more favorable to the tribes in 1962 by a decree requiring publication of the notice of hearings on acquisition of tribal land for public use. This was done in order to permit interested parties to exert their rights. ${ }^{113}$

Mali has made no effort to follow Lenin's example of nationalizing all land. Her leaders' policy is to respect existing rights, limiting their exercise only for purposes of assuring that no poor Malian debtor be treated unfairly. The policy of paying indemnities for property taken for public use was also extended to cover unexploited buildings taken for commercial or industrial purposes. ${ }^{114}$ The decree charged officials with making every effort to reach a friendly accord with the owner as to valuation before any unilateral determination and ordered that if the building were ever returned, the owners should be paid any damages resulting from use as estimated by a State Commission.

The State Mining Bureau has monopolized all valuable subsoil

108. Law No. 61-30 AN, Jan. 20, 1961, [1961] JORA No. 79, at 208.

109. Decree No. 41 bis, Jan. 26, 1961, [1961] JORMI No. 77, at 139.

110. Decree No. 40 bis, Jan. 26, 1961, [1961] JORA No. 77, at 139.

111. Law No. 61-67 AN, May 18, 1961, [1961] No. 90, at XXIII.

112. Law of May 22, 1959, discussed by Blanc, supra note 107 .

113. The procedure was applied in "Avis de demande d'immatriculation," [1962] JORM No. 121 , at 447 .

114. Law No. 63-53 AN, May 31, 1963, [1963] JORAI No. 147, at 387. 
rights. ${ }^{115}$ Only public authorities may exploit precious metals and gems, ${ }^{110}$ although these authorities may take the form of publicly licensed prospectors' cooperatives as well as state enterprises. ${ }^{117}$ Moreover, a state enterprise may assign its rights to private companies. ${ }^{118}$

Land left in private ownership is, as in Rumania and Czechoslovakia, subject to a stated policy of collectivization of agriculture, but Mali has proceeded cautiously in this area. An Institute for Rural Economy was established in 1960 to elaborate a program for agricultural planning. ${ }^{110}$ Basic crops may be purchased only at prices established by the state. ${ }^{120}$ Early emphasis was placed upon cooperatives by the organization of the Action Rurale, charged with aiding farmers to form cooperatives and with drafting laws on cooperatives. ${ }^{121}$ Similarly, the creation in 1965 of national as well as regional fishing committees promoted the cooperative pattern among fishermen. ${ }^{122}$ The commercialization of cereals is completely in the hands of cooperatives. ${ }^{123}$

To date the cooperative movement has been encouraged primarily in the area of farm services. There has been nothing comparable to Stalin's campaigns to spread producers' cooperatives in the form of collective farms. Yet something of this nature may be coming since each village has been encouraged to enlarge the "common fields," lands traditionally tilled to meet community needs. Keita suggested in 1961 that these fields be expanded by 1966 to a size computed at the rate of one hectar for each family in the village. Every village was to establish a "permanent team for labor" to spend one or two days a week working on the family plots. ${ }^{124}$ Presumably the additions necessary for expansion of the common fields were to come from plots currently being tilled privately, but no one ever explained how such transfers were to be encouraged, or whether it was rather expected that virgin land would be brought under cultivation.

Keita's Sixth Anniversary speech at the end of the plan in 1966

115. Law No. 61-68 AN, May 18, 1961, [1961] JORM No. 91, at XXIII.

116. Law No. 20 PG, Feb. 25, 1964, [1964] JORM No. 166, at 236.

117. Cooperatives are formed under Decree No. 15 PG, Feb. 3, 1964, [1964] JORM No. 163 , at 177

118. Law No. 64-3 AN, May 4, 1964, [1964] JORM No. 172, at 435.

119. Ordinance No. 59, Nov. 29, 1960, [1961] JORM No. 74, at 3.

120. As an example, see Order No. 225 AE-CP, March 4, 1961, [1961] JORM No. 80, at 259 , fixing the purchase price of rice from growers.

121. Law No. 61-66 AN, May 18, 1961, [1961] JORM No. 90, at XXII. Name changed to Direction Nationale du Développement Rural, Law No. 63-48, May 31, 1963, [1968] JORM No. 147 , at 386 .

122. Decrees Nos. 89 and 90 PG, Aug. 6, 1965, [1965] JORM No. 203, at 423.

123. Decree No. 167 PG, \& 2, Nov. 24, 1965, [1965] JORM No. 211, at 671.

124. M. KEITA, supra note 3 , at 79. 
reveals more of his thinking. ${ }^{125}$ Now he is prepared to say that agriculture must be transformed from a system of small individual and archaic family production to one of large-scale socialist production by "giving it gradually by stages new adequate structures which will permit better equipping and staffing ...." He thinks that the creation and development of increasing numbers of rural agricultural groups will meet his objective. This sounds like a move in the direction of the Soviet collective farm.

Cooperatives are not to be restricted to agriculture. They have been chosen as the desired form for expanding the productivity of artisans and handicraftsmen as well. ${ }^{126}$ Although large numbers of artisans are still to been seen working independently in Bamako, they were told in 1962 that "their true interest resides in joining producers' cooperatives." The state has placed in demonstration centers (where they are to be seen setting public examples) artisans willing to innovate by using modern machinery in their crafts. Others are being induced to join cooperatives by the offer of state loans to permit them to buy such machines. The result is expected to be development in a "semi-socialist manner," just as Lenin used to predict in the early 1920's.

\section{Civil, Commercial, and Customary Law}

As with other Marxist-oriented systems, Mali's leaders have shown no haste in revising the law of privately owned property. The civil code remains that of France, modified formally only by deletion of the chapters on marriage and the family in favor of a new family code. This leaves in force the important chapters on obligations in contract and tort and that on inheritance.

How much the code has been changed in application is hard to say, although Malian lawyers claim that socialist ideas have influenced the courts. As with other Marxian socialist legal systems, the major such influence is to be found in the withdrawal from the sphere of the code of the previously important subject of privately orwned productive property, now made the business either of the state or of cooperatives. A second influence is a tendency to aid debtors by protecting them from any sharp practices on the part of those with whom they have had to deal. Such limitations by statute include a general freezing of

125. Speech on Sixth Anniversary, supra note 18, at 4.

126. VIe CoNGres 101-02. 
rents ${ }^{127}$ and the fixing of rents for new premises in accordance with quality. ${ }^{128}$

The new Code of Marriage and Guardianship replaced the corresponding provisions of the civil code on February 3, 1962.120 It recognizes only secular marriages and imposes a fine if a religious ceremony precedes state registration. The primary target of the draftsmen was the arranged marriage, and they made consent a requisite of validity. Still tribal custom had to be met halfway, and Article 2 of the code reads: "Every request to marry a woman or young girl pledged to another with her consent is non-receivable." The fiancé under the betrothal agreement has the right to prevent the marriage of his fiancee to another until his expenses have been repaid, and judges are authorized to fix the damages. Under tribal custom the gifts on the occasion of betrothal were great, and repayment could cause severe hardship.

Again, custom was met halfway in provisions that permit the giving of gifts on the occasion of marriage. But by Article 3 a dowry, which in Mali is a husband's gift to the bride's father or head of family on the occasion of marriage, may not exceed 20,000 francs for an unmarried girl and 10,000 francs for a previously married woman. In the event of divorce on grounds of the wife's infidelity, the husband may demand return of the gifts and dowry, and vice versa. An over-amorous husband who exceeds the prescribed limits on gifts is subject to prosecution under the Criminal Code. ${ }^{130}$

Marriages contracted in violation of the prohibition of polyandryor of polygamy for those husbands who choose monogamy at the time of marriage-subject the culprit to prison terms and fines, unless a wife who is the beneficiary of a monogamy has agreed to amendment of her marriage contract. The option is designed to permit Moslems to follow Islamic custom if they desire, but they too are liable to criminal penalties if they exceed the Koranic prescription of four wives. Officials who perform prohibited marriages are to be punished with the same penalties.

The woman's role follows custom in part, for she is required to obey her husband and enjoys his protection in return. A new feature gives her civil independence with regard to her property, unless she chooses

127. Decree of Dec. 24, 1960, [1961] JORM No. 75, at 67 .

128. Order No. 331 AE-CP, April 11, 1961, [1961] JORM No. 83, at 400.

129. Law No. 62-17 AN, Feb. 3, 1962, [1962] JORM No. 111, at I. Also published in RÉpunlique du MALI, Ministère de la Justice, La Justice en Répudlique du Mali 362 (Bamako-Moscow, 1965).

130. Mali Criminal Code art. 185. 
community property in the marriage contract. She has a duty to live with her husband, the "chief of the family", but he has a corresponding duty to receive her.

The code defies custom by forbidding repudiation of the marriage contract. Moreover, in general, except in the event of the death of a spouse, dissolution is permitted only upon a judicial finding of adultery, personal excesses, cruelty, or serious injury rendering conjugal life impossible; condemnation of a spouse to a severe and degrading penalty; inveterate alcoholism; or impossibility of intercourse. The wife also has the right to demand divorce if the husband fails to meet her needs for food, clothing and housing, or to pay the dowry at the end of the period of delay set in the marriage contract. In the latter case there may be criminal prosecution of a husband who refuses with evil intent to perform his obligation.

A Malian author explains this reform of the divorce law by saying that "polygamy exists and cannot be rooted out without upsetting the social structure, the economic base of the country communities."191 The legislature could do nothing but correct excesses. Under customary law a husband who could not endure a wife arranged for him by his parents was required to maintain the family collectivity by giving her to another of its members. Moreover, the wife could be inherited by one of the brothers on the death of her husband. The code had to be framed within this context, and thus a woman remains a charge on the family into which she has married. On the other hand her emancipation is aided by the introduction of separate marital property, and she is given the right to administer the home in the absence of her husband. She is protected against the intervention of the clan or the family collectivity. In short, in the view of the Malian author, "Malian law concerning marriage and divorce draws its originality from the fact that it found a way to conciliate the exigencies of social life with the evolutionary current of the modern world."132

\section{Labor and the Civil Service}

Labor relations have, in the French tradition, been kept separate from the civil law of contract. Mali inherited a liberal Labor Code, based on the French model, and this code required only modest re-

131. Dicke Ousmane Boubou, La marriage et le ditorce au Mali, 75 Recuell Pewast 319 (1965)

132. Id. 486. 
vision and reenactment in 1962 to meet conditions of socialism. ${ }^{133}$ The code rests on the constitution's preamble, which recognizes in the French manner "for all men the right to work and to rest, the right to strike, the right to join cooperatives or trade unions of their choice for the defense of their professional interests." In traditional Marxist style the rights are paired with the duties, so that the preamble provides that

Labor is a duty of every citizen, but no one can be forced to perform any specific work except an exceptional service in the general interest, equal for all under circumstances established by law.

The location of these provisions in the preamble rather than in a bill of rights in the body of the constitution follows French rather than Soviet models, for to the Soviet mind preambles are not enough. Still, the contrast is lessened by the fact that neither the Soviet nor the Malian government accepts responsibility for providing specific jobs to the unemployed. Rather, the promise is construed to entail only direction of the economy toward full employment. Jobs derive from that, not from court orders or a government employment office. The right to work in Mali, as in Eastern Europe, is generally essentially a reaffirmation of the right to protection against discrimination in employment.

The Labor Code provides a 40 hour week and spells out the other basic provisions of the employment relation, leaving little to the individual or collective contract. The right of dismissal is limited to cases of the laborer's malfeasance or to circumstances provided in the contract. In the absence of provision for a different time, one to three months' notice must be given before terminating a contract (depending on the importance of the position held), except when there has been serious fault. Damages are payable to the victim of an abusive termination; an employer who has induced breach is held jointly responsible with the worker for damages caused. Even if there has been no inducement to breach, the second employer is liable if he knew of the original contract or continued to employ the worker after learning of his breach.

Collective bargaining follows French rules. Mixed commissions are formed by the Minister of Labor on demand of a labor union, the most representative employer or the workers themselves. The agreement must resolve specified matters listed in the code. After it has been con- 
cluded, it may be extended as in France to apply to all enterprises in the same branch of industry. Damages are recoverable in the event of breach by either side.

Labor disputes may be submitted either to the Labor Inspector of the Ministry of Labor or directly to the Labor Tribunal. The Inspector's task is to conciliate, but in the event of failure, he transmits the case to the Tribunal, which is a creature of the Council of Mrinisters named on proposal of the Ministry of Justice after notice to the Ministry of Labor. Representatives of employers and labor unions sit as assessors under a chairman who is a magistrate. Hearings are public, and parties may be represented by members of the Bar, trade associations or labor unions. As is usual under Romanist procedures, the chairman bears the burden of questioning and confronting the parties with witnesses. The Tribunal makes a further attempt at conciliation before proceeding to decision, but failing that, it decides the case on the basis of both law and equity. Appeals are prohibited (except to the President of the system) where the amount in dispute is less than 100,000 francs. A line of appeal for the cases involving larger sums lies through the Social Chamber of the Court of Appeal to the Supreme Court, but only on matters of law. If the parties refuse to execute the award, the matter is taken to the Council of Ministers for a political decision when the matter is of national concern. Strikes and lockouts are illegal during the period of attempted conciliation.

The state services are subject to a special statute on organization and recruitment, enacted in $1963^{134}$ and revised to form a "Labor Code" in 1966. ${ }^{135}$ This statute is a civil service act, fixing classification for all categories of service.

While the right to strike is enshrined in both the Constitution and the Labor Code, Party policy opposes such methods of attempting to influence results. A Party political commissar reviewing labor union policy in 1962 described their unions' tasks as that of explaining to workers

the need to increase productivity and production; to freeze wages and prices; to initiate the monetary reform; and eventually to raise the work norms which are susceptible to change on the initiative of the unions themselves. ${ }^{130}$

The commissar noted that the Party had already placed labor union

134. Decree No. 247 PG, Dec. 21, 1963, [1964] JORAI No. 161, at 48.

135. Text not yet available. For announcement, see L'Essor, Aug. 8, 1966, at 1, col. 1.

136. 2e SEMINAIRE 104-05. 
representatives on the administrative councils of the Central Bank and of the Import and Export company (SOMIEX) to open to the unions other channels of influence. He also stated that such representatives would soon be placed on the councils of all public corporations. ${ }^{\mathbf{1 0 7}}$ A few days later labor union participation was stressed in the report of the Party's political secretary to the Sixth Party Congress. ${ }^{138}$ The Party promised to raise the unions' position in all social activities higher than ever so that they might fulfill their role as a "true school of administration of the national economy." 130

The unions were criticized for having decided on their own initiative to vote "no" in DeGaulle's referendum after the Party had advised a vote of "yes." Since the Party's recommendation had been accepted by the voters, the Party commissar concluded that the "battle for the primacy of policy over the unions had been won."140

Mali's Party has had greater success in reconciling the unions to their post-revolutionary functions than did Lenin's in the 1920's. Mali sweetened the pill for unions that found that their role had changed from pressing for advantage to executing plans established by the Party, by enhancing the unions' place in enterprise administration. Yet even here the role of the unions remains subordinate since Lenin's model, which Mali's leaders have accepted, calls for predominance of the enterprise director. It is he who is ultimately responsible for success or failure.

The charter of the Office of Agricultural Products of Mali (OPAM) ${ }^{141}$ illustrates the relationship between directors and the unions in plants. Article 20 of the Labor Code provides that "[t]he Director is personally responsible for direction, administration, accomplishment of all tasks and for development of the enterprise." The labor union's role is confined to representation on the five-man Council of Direction together with members of the administration and a delegate of the Party. The pattern reminds one of Stalin's "triangle" of administration, labor union, and Party representatives, which was abolished in 1957 under threat of war and the need for quick and unencumbered administrative decision, but which reemerged under Nikita Khrushchev as a "permanent production conference." The Director worked with the con-

137. Id. 101-103.

138. VIe Congris 105.

139. 2e Seminaire 102.

140. $Y d .97$.

141. Law No. 65-7 AN, March 13, 1965, [1965] JORM No. 195, at 177. 
ference in determining production policies, although he remained at all times fully responsible for decisions.

Labor's position has been further enhanced in Mali by enactment of a law on pensions ${ }^{142}$ and one on social security, ${ }^{143}$ without which no state, socialist or not, can today meet the demands of its people. French models were followed in drafting these two statutes. The problem in these areas today is not a legislative one, but the financial one of obtaining the economic resources to pay the bill.

\section{Criminal Law}

The draftsmen of the new Criminal Code were conscious innovators They felt that the departure of the French called for drastic changes from the French code which would reflect the great differences between Malian and French conditions, morals, and traditions. In an unusual preface to the new code, ${ }^{14}$ they wrote:

The draft criminal code submitted to the National Assembly constitutes a veritable renovation in the application to our population of the law on repressive matters.

By way of illustration they cited a number of modifications. The new code places the husband as well as the wife under threat of criminal penalty for adultery or abandonment of the conjugal domicile (previously only the wife had been subject to punishment); it raises criminal penalties for political crimes and offenses, but eliminates the penalties of deportation outside the country and detention in a fortress (Mali has no outside territory, and she prefers to employ convicts in useful public works); and it eliminates the French exception from the laws against theft for thieving done within the confines of a family (Malians preferring an ultimate court sanction in such cases, knowing that a family brings a case to court only in despair of any family solution). Other new offenses were the crimes of aggravated alcoholism, outbidding other offers of dowry in order to obtain a desired wife, and failure to pay a debt in bad faith. New definitions were given vagabondage and begging, and the age of majority for criminal responsibility was reconsidered. The new attitude toward the Criminal Code was summarized in these words: "It must be a tool

142. Law No. 61-70 AN, May 18, 1961, [1961] JORAr No. 90, at XVIX.
143. Law No. 62-68 AN, Aug. 19, 1962, [1962] JORM No. 128, at 749.

144. Law No. 99 AN, Aug. 3, 1961, [1961] JORM No. 98, at I. Also published in LA JUSTICE EN RÉPUBLIQUE DU MIALI, supra note 129, at 51. 
for peace, for prevention of social trouble-not an instrument of degradation of the social climate because of application without knowledge of its provisions."

Nonetheless, Mali's code gives no hint of Soviet inspiration. The thrust of the Soviet model is concern for the welfare of the group rather than for protection of the individual. Thus, the Russian Republic's codes of 1922 and 1926 place emphasis upon the "social danger" theory of punishment, then considered an innovation among Italian theorists, rather than on the traditional "fault" theory. Soviet courts retained this emphasis, although in diminishing degree, until the post-Stalin reform of 1958 finally eliminated the judges' authority to punish socially dangerous acts "by analogy."

Likewise, the Soviet model accents the "educational" over the "retributive" approach to punishment. Except for political offenders, its dominant objective is the criminal's speedy and profitable return to society, or ideally his rehabilitation at the hands of his fellow workers with no imprisonment at all. The death penalty was abolished for periods in Soviet history, and when restored was declared to be exceptional and temporary in character, although under Stalin it was applied with noteworthy frequency.

Further, the Soviet codes graduate the severity of punishment according to a set of values peculiar to the Soviet system. Thus, theft or damage to state or cooperatively owned property is considered more serious than the same acts committed against privately owned property. Also, the conduct of commerce to obtain entrepreneurial profit is a crime. Finally, the Soviet codes introduced some new crimes relating peculiarly to socialism, notably to state economic planning. Officials directing public corporations are subject not only to dismissal for failure to meet their quotas, but to criminal penalties as well, and the penalties apply as well to officials who produce the quantity but not the quality required by the plan.

Mali's penologists have ignored all of this distinctive Soviet criminology. No reference is made to the "social danger" theory as the basis of the code. There is not even an introductory article, as in the Soviet codes, declaring its purpose to be the protection of socialist society. The French code's emphasis upon fault as a requisite for punishment is retained. Malian jurists vigorously condemn the pre-1958 Soviet punishment "by analogy" as having no place in their society.

Although it appears frequently in the code, the death penalty applies to fewer crimes than in the Soviet model. It is reserved for various 
forms of treason, ${ }^{145}$ for murder, ${ }^{146}$ armed robbery or robbery by bands, ${ }^{147}$ arson, ${ }^{148}$ destruction by explosion of habitations, ${ }^{140}$ and finally, poisoning of wells from which death results. ${ }^{150}$ There is no capital punishment for the economic crimes of theft of state property, bribery of officials, counterfeiting, or currency manipulation. Until 1964 the code did not even include a heading for "economic crimes." Directors of state enterprises are subject to no criminal penalty for failure to fulfill tasks set in the economic plan. Conducting private business for entrepreneurial profit is not a crime at all, and theft of state and cooperatively owned property is treated as no more serious an offense than theft of privately owned property. ${ }^{151}$

Indeed, the penal innovations attributable to socialism are hard to discern. The only ones that might be traced to Marxist inspiration are the definition of vagabondage, and the 1964 amendment establishing "economic crime." The article on vagabondage ${ }^{152}$ opens with the phrase, "Labor is a duty of every Malian. In consequence vagabondage is an offense." Even this offense and its treatment differ from the Soviet model. There, under legislation introduced by Khrushchev failure to perform socially useful labor was made the crime of "parasitism," punishable by banishment from the community for periods of up to five years upon a vote of a general meeting of neighbors or fellow workmen. While subsequent amendments substituted court decisions for the vigilante process, the accent continued to be on punishment by social opprobrium. Mali avoids this approach. Vagabondage is punished like any other offense in the code by trial in the ordinary way.

A 1964 amendment ${ }^{153}$ introduced the concept of "economic crime" into the code in a form perhaps inspired by the Soviet model. Fraud, contraband and other voluntary and premeditated infractions committed against economic, financial and banking institutions were made punishable, but much less severely than in the Soviet Union. The offender's property is confiscated and he is disqualified for a ten year period from his civil rights and from employment in state agencies. But Malians eschew imprisonment for such offenses and show no

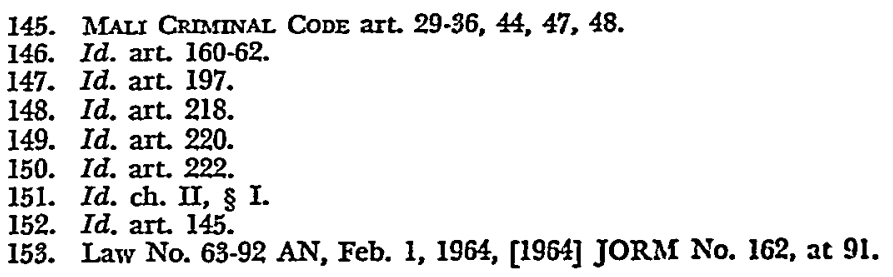


tendency to classify them as Stalin did as "sabotage," for which the penalty might be death.

In sum, the socialist influence on criminal law in Mali has been nominal. Notwithstanding the draftsmen's proud claims of originality, the major characteristic of the criminal code is the retention of French practice, modified slightly to meet Malian conditions in the details outlined in the code's preface.

\section{The Judicial System}

French influence is again paramount in the structure of the three major institutions of the judicial system-courts, prosecutors and bar -and also in the allied institution of the state notary. The constitution sets the stage with the conventional declaration in Article 42 that "The Republic of Mali assures and guarantees the independence of judicial authority, the guardian of individual liberty charged with the application in its own domain of the laws of the Republic." What difference there is in the approach to the judiciary is in attitude, not in legal terminology. Thus, all state officials, including those serving in the judicial system, have the duty to be militant in their espousal of policies established by the party, of which they all are members.

An African author writing from Senegal has seen in Mali's approach to judicial officials an imitation of the approach of certain socialist republics, ${ }^{154}$ and has found it possible to conclude that "the judicial power in the Western sense of the term has no existence of its own but is absorbed in the executive power." Such a conclusion probably requires modification after the events of 1965 discussed below, but it calls attention to a mood which must not be overlooked in evaluating Marxian influence upon the mechanism that administers justice.

Clearly, there has been a conflict in Mali between two schools of thought on the role of the judiciary. While both favor political militancy for judges, one school thought that a political court apart from the judicial system was necessary to attend to political matters such as the conduct of referenda and elections, the constitutionality of drafts presented to the legislature and of administrative acts, and claims filed by civil servants against the state. The other wanted to merge what had been a jurisdiction similar to that of Napoleon's Conseil d'Etat with the regular court.

154. M. Jeol, La Réforme de la Justice en Afrique Nolre 141 (1963). 
The political school won the first round and established their court by constitutional provision as a Cour d'Etat, but a concession was made to the other school in that appeals from the claims section went to the Supreme Court. By 1965 the overlapping jurisdictions had caused such confusion that the Party found it necessary to discuss the matter. Proposals were made to abolish the Supreme Court and established the Cour $d^{\prime} E$ tat as the sole court of last resort, but the final decision went the other way. The three sections of the Cour d'Etat were added to the Supreme Court and the Cour d'Etat was abolished, in dramatic testimony to the triumph of the men of the law. ${ }^{155}$ The merger was in fact easier than had seemed possible because the claims section had never heard a case. There was, therefore, no pending business to be transferred, but only a staff of 29 persons who were absorbed without difficulty.

The merger established a single unified court system. Even the customary law tribunals, which existed as separate entities under the French, are no longer separate. Rather, customary law problems go before the regular courts sitting with lay experts to assist the career judge. ${ }^{156}$ The system now comprises Justice of the Peace courts with both civil and criminal jurisdiction, Courts of First Instance for more serious cases, a Court of Assizes in the French manner for the most serious offenses, a Court of Appeal, and a Supreme Court of the Republic.

No effort has been made to copy the Marxian socialist model by popularizing the courts. Thus, no lay assessors sit in the courts, except as experts in customary law cases or where required by French custom in the Court of Assizes and the Labor Court. No judges are elected as they are in the People's Courts of the U.S.S.R.; instead all are appointed for life except Supreme Court judges, who sit for five years. Malians explain that because of the scarcity of trained men, appointment is the only efficient way to use manpower.

Mali has introduced no innovations in the organization of the Prosecutor's Office, the State Notaries or the Bar. The latter still represent a liberal profession, subject to the control of the judiciary. Its members have not become state functionaries as they have in Guinea.

155. Constitutional Law No. 64-1 AN [1965] JORM No. 195, at 167 (amending the constitution to combine the Cour d'Etat with the Supreme Court); Law No. 65-2, March 13, 1965, [1965] JORM No. 195, at 168 (reorganizing the Supreme Court appropriately).

156. For the organization of the judicial system, see Law No. 61.55 AN, MIay 15, 1961, [1961] JORM No. 90, at II, published also in LA JUSTICE EN RípugLQQue dU MLAs, sulpra note 129 , at 6 . 
Procedure, both civil ${ }^{157}$ and criminal, ${ }^{158}$ has been reenacted in new codes, but on the French model. Malians say the influence of socialism in this field has been to make courts more readily available to the average man than before, and to reduce the cost of justice. Thus, whereas before independence the Court of Assizes sat only once a year to hear all accumulated cases of severe crime, today it is convened at least every four months, and more often if need be. No longer do citizens sit in jail for nearly a year awaiting trial. Also, before independence the nearest court was in Dakar in what is now Senegal. Todny the court goes on circuit and the accused is tried in a sitting relatively near his home. Defense attorneys are now assigned without charge to the accused, and procedure has been simplified for certain types of cases. All trials are public, even for treason.

Departure from the Soviet model is especially marked during the preliminary investigation before trial, called the "instruction" in accordance with French practice. In the U.S.S.R. this stage of the proceedings is conducted by an investigating official appointed by the Prosecutor. Although the investigator is admonished by the code to hear evidence from both sides impartially, the Soviet Prosecutor General has indicated that abuses have occurred. In Mali, as in France, this official is a magistrate, subject to the rules governing the judiciary and in no way under the Prosecutor's control. Further, as in France, the suspect has the benefit of counsel during the preliminary investigation, while in the U.S.S.R. counsel is admitted only after the indictment has been presented to the accused.

\section{The Road Ahead}

Mali may well be on the road to becoming the fifteenth Marxian socialist state in spite of her notable divergence from the Soviet model at various points. She has established an economic system reflecting the traditional Marxist emphasis upon state industry and state economic planning. Her private enterprise sector survives and is regulated by a body of law patterned after the French Commercial Code. But this mixed economy diverges no more sharply from the model of

157. Law No, 101 AN, Aug. 18, 1961, published separately as Répudulque du MAl, Ministère de la JUSTice, Code de Procépure Givile, Commerciale ex Sociale (loi no. 101 AN-RM du 18 Aout 1961). (Imprimerie Nationale du Mali, Koulouba, no datc). Also published in LA JUSTICE EN REPUBLIQUE du MALI, supra note 129, at 146.

158. Law No. 62-66 AN, Aug. 6, 1962, [1962] JORM No. 126, at 581. Also published in LA JUSTICE EN RÉPUBLiQUe du MALI, supra note 129 , at 208. 
militant communism introduced into Russia in 1917 than did Lenin's New Economic Policy in the 1920's. Law in all spheres is conceived to be "public law," as Lenin said it must be under Marxism. Strong controls have been established over the capitalists through verification by the State Notaries of substance as well as form when transactions are registered, and also through the right reserved to the Prosecutor General to intercede in any trial to protect state interests.

Very significantly, political direction is placed in a unique political party, structured along Communist Party lines, although departing from the Soviet model in name and in its mass admission policy. State administration is left to a state apparatus in which the public participates, but far less than in the soviet system. Only at the village and city level is there the beginning of a movement toward mass participation. The doctrine of separation of powers is rejected, so that even the judiciary is under a duty to implement national policy as established by the unique party.

Finally, and most importantly for those who categorize a system by the stated goals of its leaders, there is a public commitment to Marxian socialism as the embodiment of the "universal truth", unencumbered by reservations. Keita has sought no fundamental modifications. $\mathrm{He}$ has not declared, as has Sékou Touré of Guinea, that socialism is introduced only as a means to help achieve abundance, after which the people will decide whether to move on to communism or adopt some alternative. Nor has he denounced with Senghor of Senegal the "dictatorship of the proletariat" for making Stalin's state "a monster-all powerful without soul."159

Keita has placed his people on the orthodox Marxian socialist road subject only to such adaptation as seems necessary to meet the special needs of his Malians. If wishing can influence doing, there is nothing to prevent the planned dénouement desired by Marxists everywhere: the course is set, the preliminary steps taken, the legal framework in place. Some day abundance must come from the production lines, society will be disciplined, and the state will wither away.

Can the world outside expect the final act to be played according to the scenario? Much depends upon the answer, including the programs of technical assistance and economic aid offered by several governments, notably, France, the United States, the U.S.S.R., and the People's Republic of China. A "lawyer-politico" would be brash to

159. L. Senchor, Nation et Vole Africaine du Socinllsme 51 (Paris, 1951). 
suppose that he can foretell the politics of those who will make the final curtain calls, but where so much is at stake it is tempting to try, at least by indicating the alternatives. There are strong forces at work which may restrain progress toward entering the inner circle of Marxist-oriented states. The two major ones requiring attention are French influence and the heritage of African tribal life, especially that of the Bambaras who total one quarter of the population and are by far the largest of the twelve tribes now living in what has become Mali. ${ }^{160}$

French influence is represented in the Malian pack by two strong cards: one economic and one cultural. Economically Mali needs extensive financial and technical aid. Her per capita income is low, as has been indicated, and her known resources are modest. She ranks behind much wealthier Senegal and even Guinea in the United Nations report of national incomes. ${ }^{161}$ She has no reservoir of private capital at home, and few resources to attract private investors, even if she were willing to risk what Africans call "neo-colonialism" by inviting them to bid on economic development projects. She must rely largely on grants from abroad made with as few strings as possible attached. France is potentially the main source of aid, partly bectuse of DeGaulle's desire to maintain prestige for France and her language, and partly because French leaders retain a genuine affection for the peoples for whom France felt herself so long the guardian. Mali's leaders are somewhat afraid of Paris bankers, as evidenced by their withdrawal from the Franc zone, but so many Malian leaders have been educated in France or have worked with Frenchmen that there is more mutual understanding than meets the eye of the foreign visitor. ${ }^{162}$ If French politicians can see their way to budgeting large sums of money for Mali, perhaps over the objections of less worldminded French taxpayers, Malians are likely to respond by holding to a middle road of non-commitment to the Marxian socialist family and non-acceptance of the complete Marxian institutional model. They can be expected to avoid giving the French leadership 1'eason

160. Bambaras total $1,011,000$. The next largest tribal groups are Senoufos-Miniankas with 370,000 and Peuls with 345,000. R. Adloff, West Afrucs: The French Speaking NATIONS YESTERDAY AND TODAY 23 (1964).

161. In 1958 Senegal's per capita income put her on top of the African group with a range of \$151-200 a year; Guinea was in the third group, falling between \$71-100; and Mali in the fourth group falling between $\$ 51-70$. Only Ethiopia and Upper Volta werc lower. FAO AFrica SURVEY: REPORT ON THE POSSIBILITIES OF AFRIGNN RURAL DEVELIOLMENT IN RELATION to ECONOMIC AND SOCIAL GROWTH 19 (Rome, 1962).

162. For a rich account of French rule, see R. Morgentirau, Polmtical Parties in FRENCH-SPEAFING WEST AFRICA 254-300 (1964). 
to suppose that costs might as well be cut, advisers withdrawn, and the task of maintaining the deficit economy and of molding cultural and political institutions passed wholly to those likely to reap the reward, namely the Communists of Eastern Europe and China.

Hostility to French politicians and especially to DeGaulle is not so intense in Mali as it is in Guinea. France withdrew gracefully from Bamako, but petulantly from Conakry. When Sékou Touré asked DeGaulle in 1958 how he might become independent under the proposed association, the French chief of state offered no alternative to complete severance of ties with the metropole, including those that were economic. ${ }^{163}$ Touré responded by advising his people to vote "no" in the referendum, perhaps failing to assess as dispassionately as Keita the economic need for an affirmative vote. Since separation Touré has seen the spectre of a Frenchman behind every plot to unseat him. Keita has undergone no such traumatic experience, for DeGaulle, having noted what France lost by its abrupt severance of relations with Guinea in 1958, changed his tactics. When Mali joined with Senegal in 1960 to ask for recognition of independence for the federation they proposed, DeGaulle granted their request. ${ }^{10 *}$ Mali inherited this independence from the federation after it was dissolved.

The difference between Bamako and Conakry in their relations with Paris is evident even to the foreign visitor. Bamako's offices are full of French advisers, her schools of French students and teachers. Conakry's Frenchmen have all but vanished, and those that remain have done so on their own individual initiative rather than on government assignment. For Mali France remains, then, potentially a strong source of economic and technical aid, as both sides seem prepared to foster a relationship which serves each well.

French influence in Mali is perhaps even stronger because of a second card, far less evident that the economic one. It is not to be seen in the numbers of Frenchmen or in French-financed structures. It lies unseen in the hearts and minds of large numbers of Malian intellectuals, many of whom have been educated either in France or in French schools in Africa. President Keita is a top rank graduate of the famous French lycée near Dakar named for William Ponty. ${ }^{105}$ Although this school became a cradle of African nationalists, it instilled in many prominent Africans strong humanistic values which were developed

163. Cowan, Guinea, in African One Party States 149, 167-71 (G. Carter ed. 1962).

164. R. ADLOFF, supra note 160, at 203-04.

165. For brief biographies of Keita and other West African leaders see id. at 217-19. 
further when they continued their studies in France. Senghor was one of these. He went on to graduate from the University of Paris with the highest honors yet gained by an African, and he remained in France for years, to teach and finally to serve in the French Army in World War II during which he was captured by the Germans. On his escape he served in the French Resistance.

Keita's personal history is less dramatic but no less significant. He served in Paris in the Assembly of the French Union and finally in the French National Assembly up to the very eve of independence. For him France is no ogre, but rather a font of cultural values deserving of world recognition. While he has not embraced French culture as completely as Senghor, he appreciates it more than does Touré, who has had no lasting experience in France. Touré personifies the metropole more as the colonial power for which he worked as a boy and whose capitalist enterprises he later opposed as a labor union leader until, little more than a year before independence, he was elevated to the highest government post held by an African in French Guinea. In Keita's happier experiences is to be found some explana* tion for his continuing respect for French culture and the ideals it has espoused.

No outsider can identify with certainty the cultural elements that influenced Keita's party's decision in favor of the men of the law in the struggle over the role of the Supreme Court vis-ì-vis the Cour d'Etat in 1965. Some of those who participated see the outcome as the triumph of a right approach over a wrong one, and their criteria of right and wrong seem to be grounded in French cultural values. The same cultural influences may underlie the decision to leave no gaps in the law when new codes were drafted, so as to preserve stability. ${ }^{100}$ They undoubtedly provided inspiration for an editorial in the party's newspaper, L'Essor, rebuking those who attacked the jucliciary by saying, "Without doubt there is a civic duty to speak out about the manner in which justice is rendered, but this duty stops right there, and must not push any one to dispute the social necessity of having a judicial organization." 167

Yet, Mali's leadership will not match Senghor's stalwart defense of the principle of stability of law in requiring that there be "autonomy

166. Mali Code of Civil Procedure, art. 231: "Matters not regulated by the present code remain governed by the texts in force so far as their dispositions are not contrary to those of the Code." A nearly similar provision appears in Mali Code of Criminal. Procendure art. 593.

167. "Notre Fait du Jour," L'Essor, Aug. 1, 1966, at 1, col. 4-5. 
of law vis-à-vis the party." 168 Mali's position is clear: the point of balance is placed somewhat nearer the pole of flexibility. L'Essor argues in its editorial,

It is certainly good to concern oneself with the fate of delinquents, but to move from this position to one which forgets the fate of the victims and that of society in general is to fall into the worst of aberrations. It is to support the guilty against society. That is never to be countenanced. ${ }^{109}$

Keita also exhibited his differences with Senghor when the federation broke up in 1960 soon after its formation. The issue consisted, in part, of differing ideas about what kind of leadership was necessary. Keita insisted on a single ruling party on the Communist pattern, while Senghor wanted a parliamentary system with parties responsive to the will of the people. In sum, one can surmise from all that has happened that Keita is imbued with French cultural values, but to a lesser degree than Senghor, at least with regard to forms of political leadership and the place of individuals in the community. On these issues he is far more influenced than Senghor by his studies of Marxism, his association with French Communists, and his Bambara heritage.

What Keita retains of his Bambara heritage is an enigma to a Westerner who is not an anthropologist. One can study the Bambaras, but the weight of this influence is not easy to guage, even though it provides the primary element of the "Africanism" which Keita declares himself determined to preserve. There are various leads to an understanding of this influence. A French anthropologist, in describing the life of the Bambaras, tells her readers,

We have seen that the social unit among the Bambaras was the community; it is also the work unit and the economic unit. The community owns all the goods which compose the spiritual and material patrimony .... ${ }^{170}$

Sékou Touré in analyzing his tribesmen, some of whom are Bambaras, has said as much:

Africa is essentially communaucratic. Collective living and social solidarity give to African customs a depth of humanism which many people might envy. Because of these qualities an individual

168. L. Senghor, Plantfication et Tension Morale, pt. III, at 46 (1963).

169. "Notre Fait du Jour," supra note 167, at 1, col. 3.

170. V. Paques, Les Bambara 61 (Paris, 1954). 
in Africa cannot conceive of his life outside that of the family, village or clan. The voice of the African people is faceless and nameless. ${ }^{171}$

The depth of communal feeling is exposed dramatically by a $\mathrm{Su}$ $\mathrm{Su}$, who left Guinea to come to the United States after witnessing the beheading of his sister's betrothed for theft from a Bambara. He records his shock in words quite incomprehensible to a Westerner: "Boy that I was, I understood that even as his head was separated from his body, his soul was separated from the body of his tribe. That, not his death, was the real horror of what I had seen."172

With such emphasis upon community over individual, tribal attitudes confirm rather than contradict those of Marxian socialism. They even sanctify community more than does Marxism, for the latter professes to have as its ultimate aim benefit to the individual, supporting community only as a form of organization without which the individual in modern complex society becomes as flotsam upon the sea. Such being the case, it is easy to agree with one analyst who concludes that Mali's leaders' theories 'represent a vague attempt at synthesis of the old and new in African life."173 This situation has political meaning, for it suggests that a Marxian socialist pattern of organization will not be resisted by the masses if they remain loyal to their tribal traditions. One can even agree with David Apter when he says,

In Mali, for example, underneath a rather puritannical brand of Marxism ... can be seen subtle but significant connections to the centralized politics of the ancient Bambara kingdom. The President of Mali, a descendant of the old Keita royal clans, is a president who walks like a king. ${ }^{174}$

Rather than providing a source of opposition to Marxist ideas, tribalism offers a fundamental support, so long as some of the points on which Marxism would split with tradition are not pressed too insistently. One such issue is that of monogamy, and the material reviewed suggests that the leadership is proceeding very slowly in reformation of marriage. Another is agriculture, where tribal custom has evolved a compromise between traditional common tilling of the land and private tilling by families. Keita favors extension of the com-

171. Cowan, supra note 163 , at 193.

172. Prince Modupe, I Was a Savage 27 (1957).

173. Grundy, Mali: The Prospects of 'Planned Socialism' in African Socialism 191 (W. Friedland \& C. Rosberg eds. 1964).

174. D. Apter, The Politics of Modernization 81 (1965). 
mon fields to include the whole village economy, but he has not made collective agriculture compulsory.

Still a third element is the role played by traditional elites. Keita's discipined, politically oriented, Marxist party has no room for those members of the traditional elite who are unwilling to conform to the new model. An astute anthropologist with wide experience in West Africa has noted in many of the one-party states a reversion to tribal structure coupled with a strengthening of traditional elites among people who are not receptive to mass mobilization except in international crises. ${ }^{175}$ In his view, Mali presently represents a theater of successful mobilization under a political party of an action type; but retrogression may already be setting in, for as early as 1963 the party established special schools for party cadres, and leading cabinet ministers took six weeks from work to supervise these schools. He might have added that every issue of L'Essor is devoted to impassioned calls to service in construction of the new Mali, and this may herald further difficulties in creating the "avant-garde" party necessary to hasten modernization of society in a Marxist mold.

In sum, if the influences surveyed have been seen correctly, the restraints likely to come from forces outside Marxist ideology on Mali's progression down the road to full membership in the Marxian socialist legal family on any formal basis do not lurk in tribalism, so long as the change is not too rigorously enforced on family custom or in agriculture, and so long as political education is promoted with fervor. The potential limitations lie hidden primarily in the hearts of men imbued as youthful intellectuals with French humanistic culture, even when they have not accepted conversion to Christianity, and also in the minds of French politicians currently interested in maintaining France's affectionate generosity toward Mali.

There remains one further factor which may be a counterweight to both restraints: the Marxist education of the men putting or about to put their feet on the ladder of power. It is this which has aroused one analyst to conclude that, "communist theses, arguments and propaganda are already playing a big role in Bamako."170 He finds also that various government departments, the trade unions, women's and youth organizations, and even the Party are falling into the hands of

\footnotetext{
175. Wallerstein, The Decline of the Party in the Single-Parly African States, in

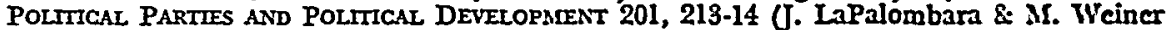
eds. 1966).

176. F. Schatren, Comarunisar in Africa 166 (1966).
} 
orthodox Marxist elements. Some of these men and women have been trained in Soviet universities, and some by Soviet teachers in Mali. Indubitably, some transformation through education is occurring, although students have not, perhaps, accepted the lessons taught as thoroughly as might be supposed. There are well stocked libraries of Marxian and Soviet literature in French translation in Bamako, but reports suggest that it is the rare student who reads this literature avidly, if at all. The quality of Soviet-sponsored education lags, partly because Soviet teachers have neglected French for many years and only now are seeking to catch up. Some Malians who return from Eastern European schools are unhappy with their treatment by townspeople there. Factors such as these tend to reduce the favorable impact of Marxist education, but the impact is present and continuing and no effort is spared to increase it.

But, Marxist education and Soviet aid could be completely contaminated if the Soviets were to indicate at any time a desire to dominate. When pressed too hard, Touré turned against those he thought his friends and embarked on his own theoretical and institutional path, as Senghor had done before him under a like threat to power. Nationalism runs strong in West Africa, even among those who are oriented toward Marxism, and it could be awakened also in Mali to the detriment of Eastern Europeans and the Communist Chinese. The words of a Nigerian Roman Catholic priest might be prophetic if Marxists from abroad press too hard. In his view some of the self. declared orthodox Marxists of Africa are "incapable of liberating themselves from their colonial intellectual enslavement."177 At the moment they can see the potential of "neo-colonialism" only in the old imperialists, but if the fountain-head of Marxism were to threaten enslavement of a new sort, there could be a sudden change of view. He explains African socialist motivation as "an expression of the desire of all Africans to find themselves, be themselves, and assert themselves. It is a crystallization of the African genius and a declaration of ideological independence in a world flooded with learned masters."178 (Emphasis in original.)

Thus, if the African personality were to be threatened or appear to Malians to be threatened by Communists from abroad, there could be swift severing of what appears to some to be an umbilical cord linking the youthful Malian state to the Marxist ideological camp. The

177. Bede ONuoha, The Elements of African Socialism 30 (1965).

178. Id. 
consequences of such a rupture might will be reflected in future institutional development. The end would come to acceptance of "the eternal truth of Marxian socialism," and Mali might turn as Senghor has turned, to foster a "mutation" into a new kind of socialism, rejecting institutional development in the Marxian model. It might strike out on its own on a novel socialist-oriented path, but with a hand held out to non-Marxist states, notably France, for help which would smooth the way by providing both economic aid and the institutional advice which commonly accompanies such aid. 